\title{
A key to the known larvae of South American EImidae (Coleoptera: Byrrhoidea), with a description of the mature larva of Macrelmis saltensis Manzo.
}

\author{
V. $\operatorname{Manzo}^{1 *}$, M. Archangelsky² \\ ${ }^{1}$ CONICET - Facultad de Ciencias Naturales e IML, INSUE, Universidad Nacional de Tucumán, Miguel Lillo 205, (4000), Tucumán, \\ Argentina. \\ 2 CONICET - Laboratorio de Investigaciones en Ecología y Sistemática Animal (LIESA), Facultad de Ciencias Naturales, Universidad \\ Nacional de La Patagonia “San Juan Bosco”, Sarmiento 849, 9200 Esquel, Chubut; Argentina.
}

\begin{abstract}
A key to identify the known mature larvae of the South American genera of the family Elmidae is provided. The key includes seven genera presently assigned to the subfamily Larainae and 15 genera assigned to the subfamily Elminae. New distributional data for all genera and a checklist of described larvae are also included. The mature larva of Macrelmis saltensis Manzo is described and illustrated for the first time, and compared to other known larvae of the granigera species-group. Distributional notes for $M$. saltensis increase its known range to the north, this being the first citation of the species for Bolivia. Macrelmis isis (Hinton) is also cited for the first time for Bolivia.
\end{abstract}

Keywords: Elmidae, larvae, identification key, Macrelmis, South America.

\section{Introduction}

The family Elmidae (riffle beetles) is a large cosmopolitan family divided into two subfamilies, Elminae and Larainae, both of which are present in the Neotropical Region. With more than 330 described species in 44 genera in this region (Manzo 2006a), riffle beetles are very common, especially in lotic habitats. Larvae and adults are found together in streams and rivers all year long. Despite being so widely distributed and very common, preimaginal stages of elmids are poorly known in South America. Descriptions of elmid larvae, especially from tropical regions, are rarely found in the literature (Čiampor \& Ribera 2006). For the Neotropical region, at a specific level, less than $10 \%$ of the larvae have been described (Table 1). However in recent years larval studies of elmids have increased (Archangelsky \& Manzo 2006, 2007, Manzo \& Archangelsky 2001, Springer \& Rivas 2003, Manzo 2006a, b).

A key to identify adults of all known South American genera has been recently published (Manzo 2005), but a similar key for larvae is lacking. Nevertheless some

\footnotetext{
* Corresponding author: E-mail: vmanzo@csnat.unt.edu.ar
}

useful references exist. Hinton (1940) described the larvae of several genera from Mexico. Other important contributions are those by Spangler \& Santiago (1987) and Spangler \& Santiago-Fragoso (1992) who studied the Larainae of Central America, describing the larvae of several genera. Additional studies dealing with larval descriptions are those by Brown $(1970,1971$, and 1981) and Spangler (1966, 1990). Other important contributions are those by Bertrand $(1956,1965,1972)$ in which he summarizes the knowledge of the immature stages of Byrrhoidea including Elmidae as part of Dryopidae. Finally Archangelsky \& Manzo (2006) provide a key to identify the larvae of all known American Larainae.

Even though the larvae of only 22 genera $(56 \%)$ of the 39 genera present in South America are known, we consider it important to publish a key for the known mature larvae of this family. This preliminary key will allow separating those larvae that are unknown from those already described, and will help in the association between adults and larvae. It will also be an important tool for many ecologists. It is important to point out that the 17 unknown genera are mainly in the northern half of South America, so the key is particularly useful in the southern half of South America. Since no character allows separating 
Table 1. Checklist of genera and species with larvae described from the Neotropical region and number of species in each genus cited.

\begin{tabular}{|c|c|}
\hline Genus & Number of species \\
\hline \multicolumn{2}{|l|}{ Subfamily Larainae } \\
\hline$\overline{\text { Disersus Sharp } 1882}$ & 10 \\
\hline \multicolumn{2}{|l|}{ D. longipennis Sharp 1882} \\
\hline Hexanchorus Sharp 1882 & 14 \\
\hline \multicolumn{2}{|l|}{ H. gracilipes Sharp 1882} \\
\hline \multicolumn{2}{|l|}{ H. caraibus (Coquerel 1851) } \\
\hline Hispaniolara Brown 1981 & 1 \\
\hline \multicolumn{2}{|l|}{ H. farri Brown 1981} \\
\hline Hydora Broun 1882 & 2 \\
\hline \multicolumn{2}{|l|}{ H. annectens Spangler \& Brown 1981} \\
\hline Pseudodisersus Brown 1981 & 1 \\
\hline \multicolumn{2}{|l|}{ P. goudotii (Guérin - Méneville 1843) } \\
\hline Phanocerus Sharp 1882 & 4 \\
\hline \multicolumn{2}{|l|}{ P. clavicornis Sharp 1882 and 1 larvae not assigned to any known species } \\
\hline Pharceonus Spangler \& Santiago 1992 & 1 \\
\hline \multicolumn{2}{|l|}{ P. volcanus Spangler \& Santiago 1992} \\
\hline Roraima Kodada \& Jäch 1999 & 1 \\
\hline \multicolumn{2}{|l|}{ R. carinata Kodada \& Jäch 1999} \\
\hline Subfamily Elminae & \\
\hline Austrelmis Brown 1984 & 21 \\
\hline
\end{tabular}

A. lata (Hinton 1940)

Austrolimnius Carter \& Zeck 1829

1 larva not assigned to any known species

Cylloepus Erickson 1847

1 larva not assigned to any known species

Heterelmis Sharp 1882

H. longula Sharp 1887 and 2 larvae not assigned to any known species

Hexacylloepus Hinton 1940

H. ferrugineus (Horn1870)

Huleechius Brown 1981

H. spinipes (Hinton 1936)

H. marroni Brown 1981

Luchoelmis Spangler \& Staines, 2001

L. cekalovici Spangler \& Staines, 2001

Macrelmis Mostchulsky 1859

M. striata (Sharp 1882)

M. granigera (Sharp 1882)

M. isis Hinton 1946

M. saltensis Manzo 2003 and 3 larvae not assigned to any known species

Microcylloepus Hinton 1935

M. inaequalis (Sharp 1882)

Neocylloepus Brown 1970 
Table 1. (continued).

\begin{tabular}{|c|c|}
\hline Genus & Number of species \\
\hline $\begin{array}{l}\text { N. boeseli Brown } 1970 \\
\text { N. sculptipennis (Sharp 1882) } \\
\text { N. sandersoni Brown } 1970\end{array}$ & \\
\hline $\begin{array}{l}\text { Neoelmis Musgrave } 1935 \\
2 \text { larvae not assigned to any known species }\end{array}$ & 47 \\
\hline $\begin{array}{r}\text { Phanoceroides Hinton } 1939 \\
\text { P. aquatica } \text { Hinton } 1939\end{array}$ & 1 \\
\hline $\begin{array}{l}\text { Stegoelmis Hinton } 1939 \\
\quad \text { S. selva Spangler } 1990\end{array}$ & 11 \\
\hline $\begin{array}{l}\text { Stethelmis Hinton, } 1945 \\
\text { S. kaszabi Hinton, } 1970\end{array}$ & 2 \\
\hline $\begin{array}{l}\text { Tolriolus Hinton } 1940 \\
\text { T. ungulatus Hinton } 1940\end{array}$ & 1 \\
\hline $\begin{array}{l}\text { Xenelmis Hinton } 1936 \\
\quad \text { X. bufo (Sharp 1882) } \\
\text { X. sandersoni Brown } 1985 \\
\text { X. uruzuensis Manzo } 2006\end{array}$ & 13 \\
\hline
\end{tabular}

between larvae of the two subfamilies, this key includes all known elmid larvae of South America.

We also include the description of the larva of Macrelmis saltensis, compare it to other known larvae of the granigera species - group, and add some distributional notes of M. saltensis and M. isis.

\section{Material and methods}

Most of the material examined for this key is from the entomological collections in the Fundación - Instituto Miguel Lillo, Tucumán, Argentina (FIML). Additional specimens were borrowed from National Museum of Natural History, Smithsonian Institution, USA (NMNH, SI) and Universidad Mayor de San Simón de Bolivia, Unidad de Limnología y Recursos Acuáticos (UNSS ULRA), Cochabamba, Bolivia. Information about some genera for which specimens were not available was obtained from literature (see Table 2).

Specimens of Macrelmis saltensis were fixed in the field and stored in $75 \%$ ethyl alcohol. Specimens were then cleared in lactic acid, dissected and mounted on slides in Hoyer's medium for observation and description. Drawings were done using Leica DMLB and Olympus BH-2 compound microscopes, and a Leica Wild M3Z, all with camera lucida. To be consistent with larval morphological nomenclature, we follow Lawrence (1991) and Kodada \& Jäch (1999).

\section{Results}

Key for the identification of the known mature larvae of South American Elmidae*

1- Body strongly flattened dorsoventrally (platyform larvae); lateral margins of thorax and abdomen falcate; abdomen with pleural sclerites on segments I-VIII (Fig. 1)... 2

- Body cylindrical, subcylindrical or slightly flattened dorsoventrally (eruciform larvae); lateral margins of thorax and abdomen never falcate (Fig. 3); abdomen with pleural sclerites on segments I-IV, I-V, I-VI, I-VII, I-VIII or pleural suture on abdominal segments I-IX ... 4

2- Ventral region of prothorax with two large anterolateral sclerites, one on each side and a prosternal sclerite (Fig. 8); margins of thoracic sclerites rounded; margins of abdominal sclerites slightly falcate. Brazil... Phanoceroides

- Ventral region of prothorax with five sclerites, one anterolateral pair, one lateral pair and one posteromedian sclerite (Fig. 1); lateral margins of thoracic and abdominal sclerites strongly falcate... $\mathbf{3}$

* Genera not included in this key: Neblinagena, Potamophilops, Epodelmis, Gyrelmis, Hintonelmis, Holcelmis, Jolyelmis, Neolimnius, Notelmis, Onychelmis, Oolimnius, Pagelmis, Pilielmis, Portelmis, Stenhelmoides, Tolmerelmis and Tyletelmis. 
Table 2. Distribution and bibliographic references of the species examined.

\begin{tabular}{|c|c|}
\hline Subfamily Larainae & Distributions and References \\
\hline Disersus spp Sharp 1882 & Brazil - Peru (FIML and NMNH, SI) \\
\hline Hexanchorus sp Sharp 1882 & Argentina (FIML) \\
\hline Hispaniolara farri Brown 1981 & Spangler \& Santiago - Fragoso 1992 \\
\hline Hydora annectens Spangler \& Brown 1882 & Argentina (FIML) \\
\hline Pseudodisersus sp Brown 1981 & Brazil - Colombia (FIML and NMNH, SI) \\
\hline Phanocerus spp Sharp 1882 & Argentina (FIML) \\
\hline Pharceonus volcanus Spangler \& Santiago 1992 & Colombia (FIML) \\
\hline Roraima carinata Kodada \& Jäch 1999 & Kodada \& Jäch 1999 \\
\hline \multicolumn{2}{|l|}{ Subfamily Elminae } \\
\hline Austrelmis spp Brown 1984 & Argentina - Bolivia - Peru (FIML and UNSS, ULRA) \\
\hline Austrolimnius spp Carter \& Zeck 1829 & Argentina - Bolivia - Colombia (FIML) \\
\hline Cylloepus sp Erickson 1847 & Argentina (FIML) \\
\hline Cylloepus parkeri Sanderson 1953 & USA (FIML) \\
\hline Heterelmis spp Sharp 1882 & Argentina - Bolivia (FIML and UNSS, ULRA) \\
\hline Hexacylloepus sp Hinton 1940 & Argentina (FIML) \\
\hline Huleechius sp Brown 1981 & Bolivia (FIML) \\
\hline Huleechius marroni Brown 1981 & Mexico (FIML) \\
\hline Luchoelmis cekalovici Spangler \& Staines 2001 & Argentina (FIML) \\
\hline Macrelmis sp Mostchulsky 1859 & Colombia (FIML) \\
\hline Macrelmis saltensis Manzo 2003 & Bolivia (FIML) \\
\hline Macrelmis isis Hinton 1946 & Argentina and Bolivia (FIML) \\
\hline Microcylloepus Hinton 1935 & Argentina - Bolivia (FIML and UNSS, ULRA) \\
\hline Neocylloepus sp Brown 1970 & Bolivia (FIML) \\
\hline Neoelmis spp Musgrave 1935 & Argentina - Bolivia and Colombia (FIML and UNSS, ULRA) \\
\hline Phanoceroides acuatica Hinton 1939 & Hinton 1939 \\
\hline Stegoelmis sp Hinton 1939 & Brazil (FIML) \\
\hline Stethelmis kaszabi Hinton 1970 & Argentina (FIML) \\
\hline Tolriolus ungulatus Hinton 1940 & Hinton 1940 \\
\hline Xenelmis uruzuensis Manzo 2006 & Argentina (FIML) \\
\hline
\end{tabular}

3- Last abdominal segment not abruptly narrowed at middle, apex slightly emarginated (Fig. 1). USA, Central America, West Indies, Colombia, Trinidad and Tobago, Peru, Paraguay and Argentina... Phanocerus

- Last abdominal segment abruptly narrowed at middle, apex deeply emarginated (Fig. 2). Panama, Costa Rica, Venezuela, Colombia, Ecuador and Peru... Pharceonus
4-Body cylindrical; pleural suture extending to middle of abdominal segment IX (Fig. 5). USA, Central America, Peru, Ecuador, Brazil, Bolivia, Paraguay and Argentina... Cylloepus

- Body shape variable; abdominal segment IX without pleural suture... 5

5- Sensory appendage of second antennomere very long, as long or longer than first antennomere (Fig. 9); 


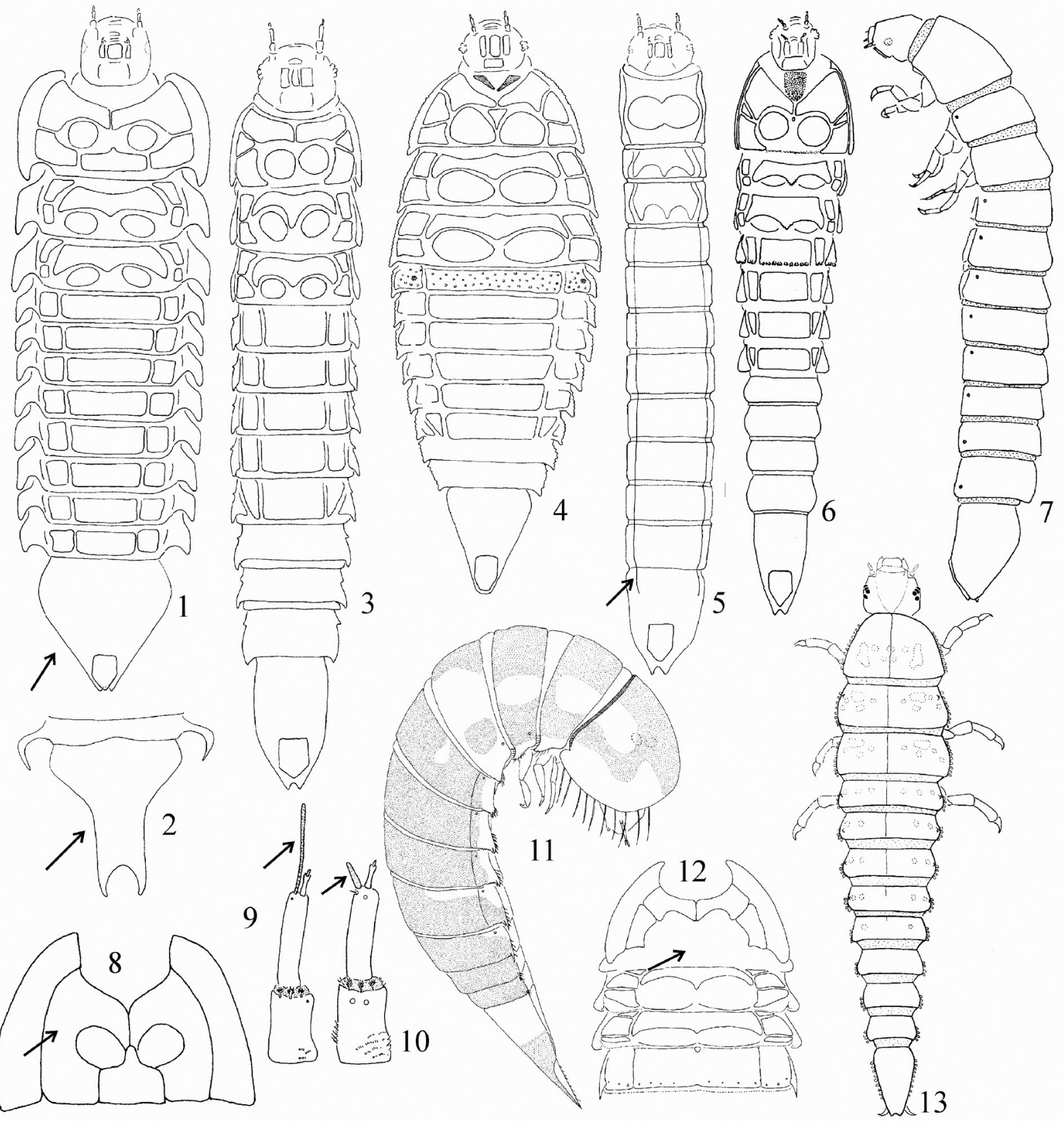

Figs. 1 - 13. Elmidae. Larainae (Figs 1 - 4), larvae. 1 Phanocerus sp., ventral view; 2 Pharceonus sp., dorsal view of last abdominal segments; 3 Pseudodisersus sp., ventral view; 4 Hexanchorus sp., ventral view. Elminae (Figs 5 - 13), larvae. 5 Cylloepus sp., ventral view; 6 - 7 Luchoelmis cekalovici, 6 ventral view, 7 lateral view; 8 Phanoceroides acuatica, thorax, ventral view (modified from Hinton 1939); 9 Austrolimnius sp., antenna; 10 Macrelmis isis, antenna; 11 - 12 Xenelmis sp., 11 lateral view, 12 thorax, ventral view; 13 Stethelmis kaszabi, dorsal view. 
pleural sclerites on abdominal segments I-VII; tubercles on thoracic and abdominal segments arranged in a variable number of longitudinal rows. Central America, French Guiana, Colombia, Venezuela, Ecuador, Brazil, Bolivia, Paraguay, Chile and Argentina... Austrolimnius

- Sensory appendage of second antennomere short, shorter than first antennomere (Fig. 10); number of pleural sclerites on abdominal segments variable; arrangement of tubercles on thoracic and abdominal segments variable... 6

6- Pleural sclerites on abdominal segments I-IV (Figs. 6 and 7). Chile and Argentina... Luchoelmis

- Pleural sclerites on abdominal segments I-V, I-VI, or I-VII... 7

7- Pleural sclerites on abdominal segments I-V (Fig. 3)... 8

- Pleural sclerites on abdominal segments I-VI or IVII. 9

8- Body elongate, subcylindrical; lateral margins of the terga of meso-, metathorax and abdominal segments slightly expanded; abdominal segment VI with an incomplete pleural suture. Mature larva up to $15.5 \mathrm{~mm}$ in length (Fig. 3). Costa Rica, Panama, Colombia and Ecuador... Pseudodisersus

- Body elongate, narrowing behind abdominal segment I; lateral margins of the terga of meso-, metathorax and abdominal segments not expanded; abdominal segment VI without a pleural suture. Mature larva up to 6.0 $\mathrm{mm}$ in length. (Fig.13). Chile and Argentina... Stethelmis

9- Pleural sclerites on abdominal segments I-VI, sometimes segment VII may have a partial pleural suture; procoxal cavities open... 10

- Pleural sclerites on abdominal segments I-VII; procoxal cavities open or closed... 13

10-Ventral region of prothorax with four sclerites: one anterior pair, one posterior pair; ventral region of mesoand metathorax with seven sclerites: one anterior and three lateral pairs (Fig. 12); body convex, hemispherical in cross section. Mature larva at most $3.0 \mathrm{~mm}$ long (Fig. 11). USA; Central America, Ecuador, Peru, Brazil, Paraguay, Bolivia and Argentina... Xenelmis

- Ventral region of prothorax with seven sclerites: one anterolateral pair, two lateral pairs, and one anteromedian sclerite; ventral region of meso- and metathorax with five sclerites: one anterior sclerite and two lateral pairs (Fig. 4); body shape variable. Mature larvae over $4.0 \mathrm{~mm}$ long... 11
11- Body fusiform, slightly depressed dorsoventrally; (Fig. 4); apex of last abdominal segment rounded; posterior margin of abdominal segment VIII with a large tubercle on each side; abdominal terga I-VIII without tubercles arranged in longitudinal rows. Length up to 5.0 $\mathrm{mm}$. Central América, Caribbean, Trinidad and Tobago, Ecuador, Peru, Brazil, Bolivia, Paraguay and Argentina... Hexanchorus

- Body cylindrical or subcylindrical, sides subparallel; apex of last abdominal segment emarginated; posterior margin of abdominal segment VIII without large tubercles; abdominal terga I-VIII with tubercles arranged in longitudinal rows. Length up to $10.0 \mathrm{~mm} . . .12$

12- Body cylindrical, sides subparallel; tergal tubercles of prothorax and abdominal segments I-VIII arranged in four longitudinal rows, those of meso- and metathorax arranged in six rows; length of abdominal segment IX less than the length of abdominal segments V-VIII combined (Fig. 14). Length up to $16.0 \mathrm{~mm}$. Guatemala, Costa Rica, Panama, Ecuador, Peru, Venezuela, Colombia and Ecuador... Disersus

- Body subcylindrical; tergal tubercles of thorax and abdominal segments I-VIII arranged in one longitudinal row on each side of the median line (sometimes absent); length of abdominal segment IX more than the length of abdominal segments V-VIII combined (Fig. 16). Length up to $10.0 \mathrm{~mm}$. French Guiana, Venezuela, Colombia, Ecuador, Peru and Brazil... Stegoelmis

13- Last abdominal segment long and slender, three times longer than wide (Fig. 21). USA, Central America, Caribbean, French Guiana, Venezuela, Peru, Brazil, Paraguay and Argentina... Hexacylloepus

- Last abdominal segment variable in shape and length, but never three times longer than wide... 14

14- Procoxal cavities open. Cuticle with modified setae and granules: prominent, round granules, each granule with rounded, adpressed scale with vein-like surface structures; papillate projections, each projection with an elongate scale with vein-like surface structures; small, flat, elliptical granules with short, fringed setae; clavate setae with setose surface and fine, moderately long, hair-like setae. Venezuela... Roraima

- Procoxal cavities closed (Fig. 15); cuticle with tubercles and setae but not as above... 15

15- Ventral region of meso- and metathorax with five sclerites (Fig. 15): one anterior subpentagonal, and two lateral pairs; thoracic and abdominal terga with setiferous tubercles, sometimes arranged in longitudinal rows... 16 


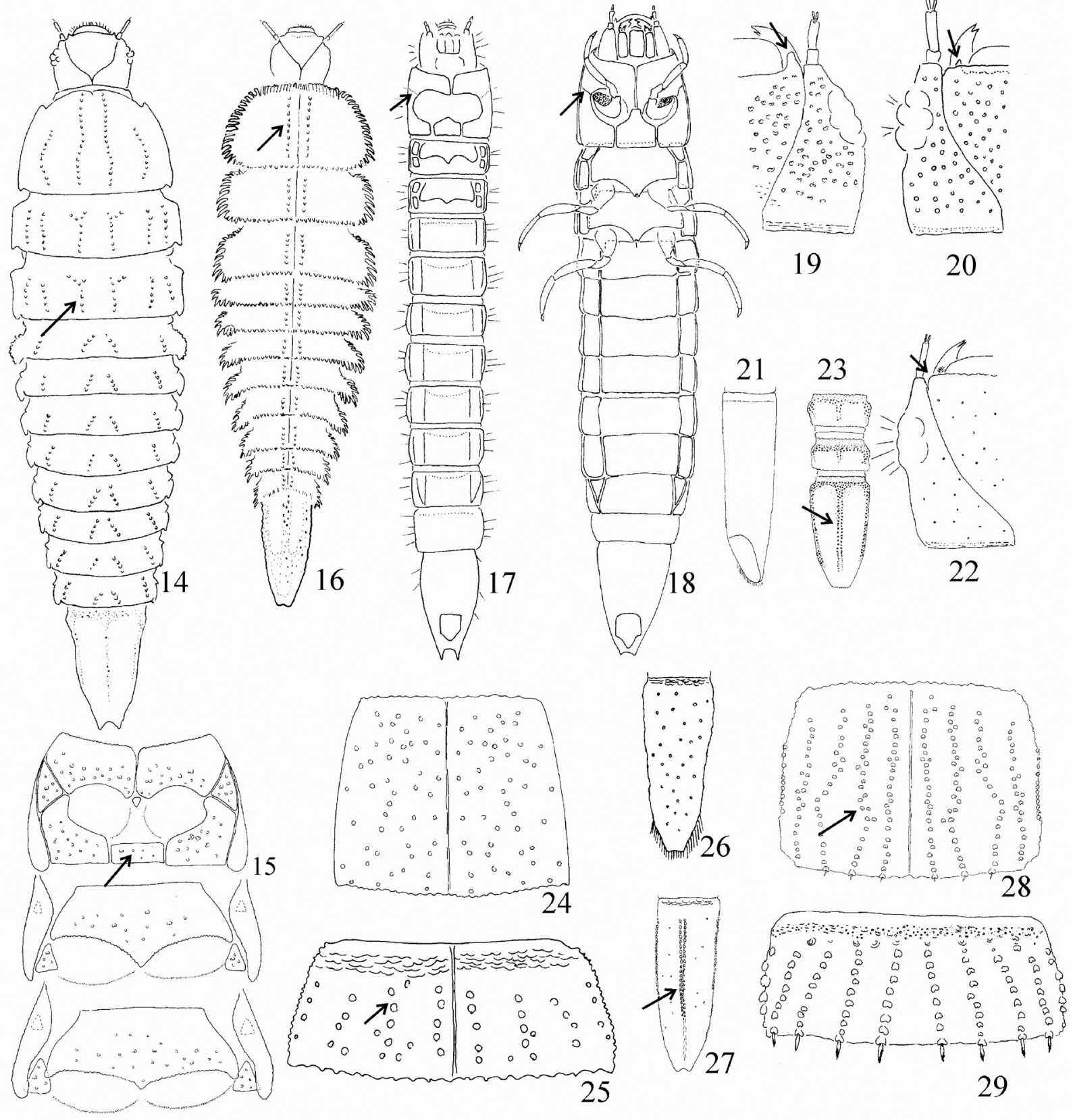

Figs. 14 - 29. Elmidae. Larainae (Figs 14 - 15), larvae. 14 Disersus sp., dorsal view (modified from Spangler \& Santiago - Fragoso 1992); 15 Hydora annectens , thorax, ventral view. Elminae (Figs 16 - 29), larvae. 16 Stegoelmis sp., dorsal view (modified from Spangler 1990 ); 17 Huleechius sp., ventral view; 18 - 19 Macrelmis sp., 18 ventral view, 19 head capsule, dorsal view; 20 Austrelmis sp., head capsule, dorsal view; 21 Hexacylloepus sp., lateral view of last abdominal segment; 22 Neoelmis sp., dorsal view, head capsule,; 23 Neocylloepus sp., last abdominal segments; 24 - 26 Microcylloepus sp., 24 pronotum, 25 first abdominal tergum, 26 last abdominal segment; 27 - 29 Heterelmis sp., 27 last abdominal segment; 28 pronotum, 29 first abdominal tergum. 


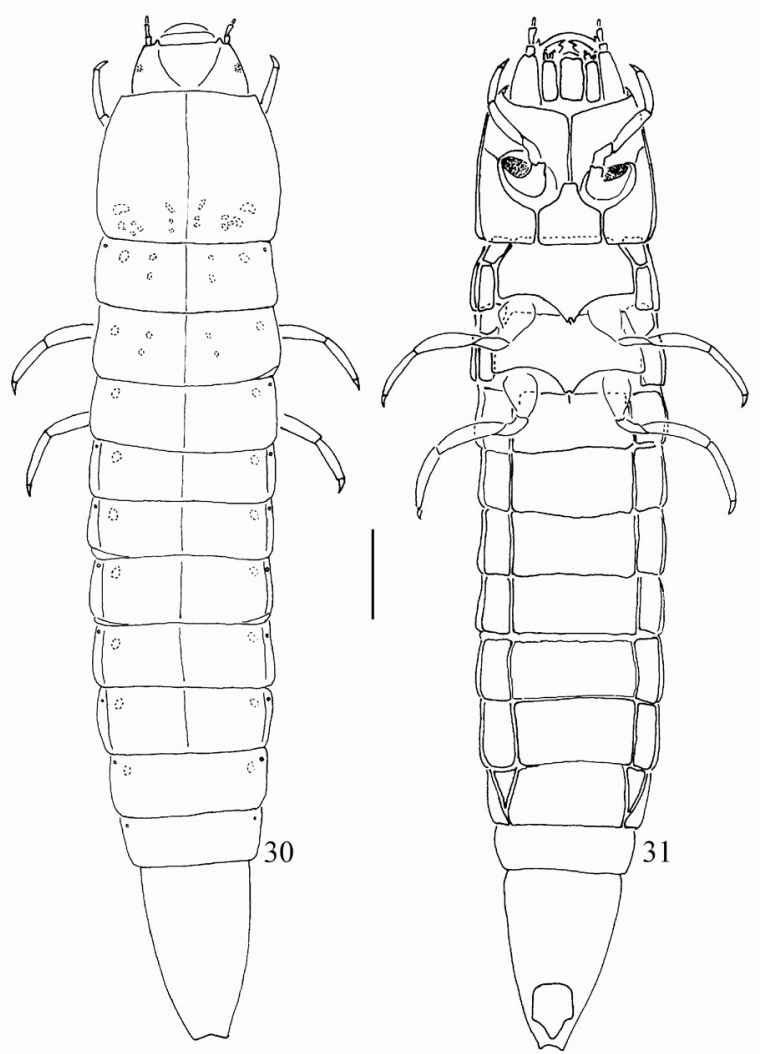

Figs. 30 - 31. Macrelmis saltensis Manzo, larva. 30 habitus, dorsal view; 31 habitus, ventral view. Scale bars $=0.50 \mathrm{~mm}$.

- Ventral region of meso- and metathorax with seven sclerites: one anterior subpentagonal, and three lateral pairs; thoracic and abdominal terga with setiferous tubercles arranged (although sometimes partially) in longitudinal rows... 21

16- Lateral margins of meso- and metathoracic terga strongly bent ventromedially; meso- and metathorax with five ventral sclerites: one anterior, subpentagonal, and two lateral pairs subtriangular (one pair inconspicuous, under the edge of the tergite) (Fig. 15). Chile and Argentina... Hydora

- Lateral margins of meso- and metathoracic terga not bent ventromedially; meso- and metathorax with five ventral sclerites: one anterior, subpentagonal, and two lateral pairs conspicuous, subrectangular... 17

17- Anterior border of head capsule with a tooth on each side, between base of antennae and clypeus or on the sides of the clypeus (Figs. 19 and 20)... 18

- Anterior border of head capsule without teeth (Fig. 22). USA, Mexico, Central America, Caribbean, Ecua- dor, Trinidad and Tobago, Venezuela, Peru, Colombia, Bolivia, Brazil, Paraguay, Chile and Argentina... Neoelmis

18- Anterior border of frons with a large blunt tooth on each side, between base of antennae and clypeus (Fig. 19); lateral margin of clypeus without teeth; body shape variable... 19

- Anterior border of frons without teeth between base of antennae and clypeus; lateral margin of clypeus with a small tooth on each side (Fig. 20); body subtriangular; cuticle usually with dark markings; tergum of abdominal segment IX usually with a median keel. Ecuador, Peru, Bolivia, Chile and Argentina... Austrelmis

19- Body flattened dorsoventrally; thoracic and first eight abdominal terga wider than long; suture from procoxal cavity to lateral margin conspicuous (Fig. 18); mature larva dark brown, almost black. USA, Mexico, Central America, French Guiana, Colombia, Venezuela, Trinidad and Tobago, Peru, Ecuador, Brazil, Bolivia, Paraguay, Chile and Argentina... Macrelmis

- Body subcylindrical, not flattened; thoracic and first eight abdominal terga as wide as long... 20

20- Tergum of abdominal segment IX with a median keel (Fig. 23); suture from procoxal cavity to lateral margin conspicuous. USA, Central America, and Bolivia... Neocylloepus

- Tergum of abdominal segment IX convex, without median keel; suture from procoxal cavity to lateral margin inconspicuous (Fig. 17). USA, Mexico, Ecuador, Bolivia and Argentina... Huleechius

21- Tergal tubercles of pronotum and abdominal segment IX randomly distributed (Figs. 24 and 26), not forming longitudinal rows; tubercles on remaining terga arranged in longitudinal rows (Fig. 25). USA, Central America, Caribbean, Trinidad and Tobago, French Guiana, Brazil, Peru, Chile, Paraguay and Argentina...

\section{Microcylloepus}

- Tergal tubercles of thorax and first eight abdominal segments arranged in 8 or 10 longitudinal rows (Figs. 28 and 29); tergal tubercles of abdominal segment IX arranged in two median and two lateral rows (Fig. 27). USA, Mexico, Central America, Caribbean, Venezuela, Trinidad and Tobago, Ecuador, Peru, Brazil, Bolivia, Chile and Argentina... Heterelmis

\section{Description of the mature larvae of Macrelmis saltensis Manzo}

Body (Figs. 30 and 31): elongate, flattened dorsoventrally, subtriangular in cross-section, sides of body subparallel. Length $5.70 \mathrm{~mm}$, width $1.15 \mathrm{~mm}$ (at base of 


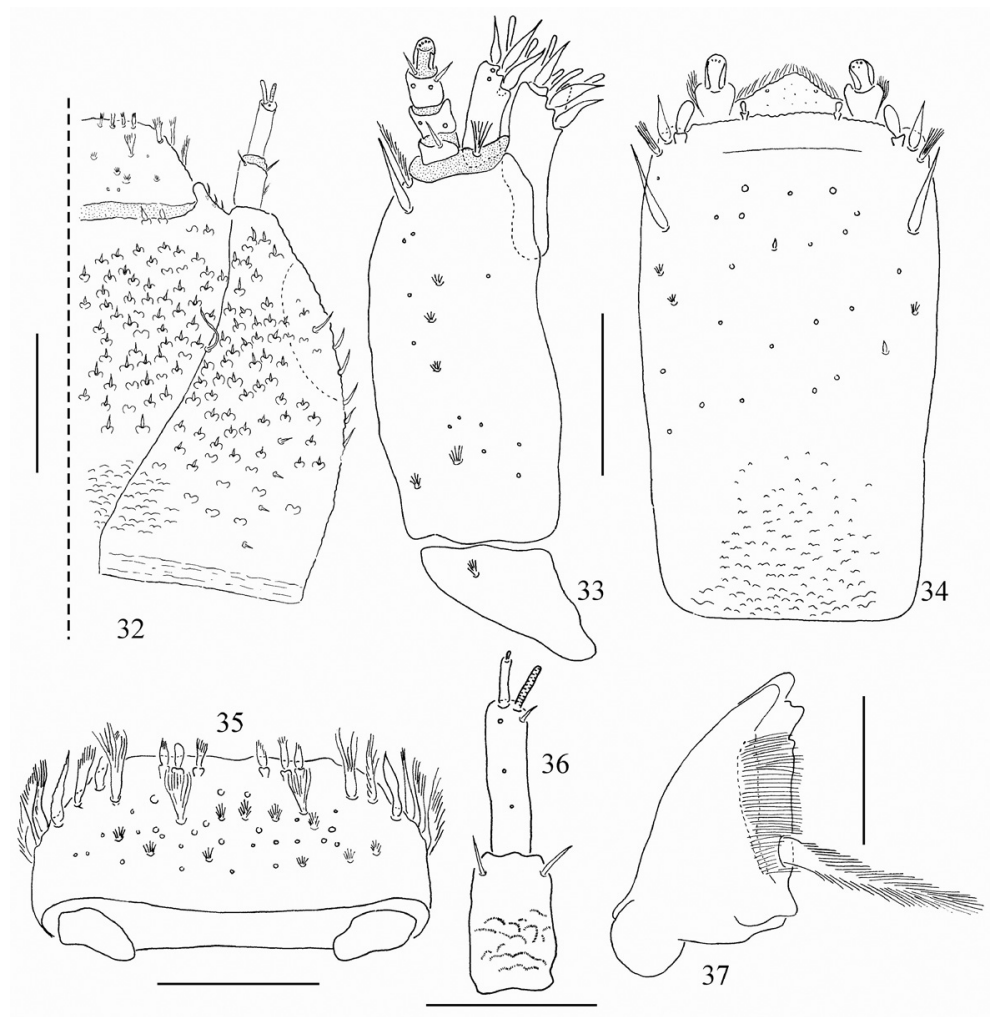

Figs. 32 - 37. Macrelmis saltensis Manzo, larva. 32 head capsule, dorsal view; 33 maxilla, ventral view; 34 labium, ventral view; 35 labrum, dorsal view; 36 right antenna; 37 mandible, dorsal view. Scale bars: figs 32, 35 and $37=0.20 \mathrm{~mm}$; figs 33,34 and $36=0.10 \mathrm{~mm}$.

metathorax). Cuticle shiny, brown; antennae, mouthparts, distal margin of clypeus and legs lighter in color; ocular area yellowish. Posterior margin of all segments, except ninth, with a complete ring of tubercles from which arise flat setae branched distally (Fig. 44).

Head capsule (Fig. 32 ) wider at middle, partially retracted within thorax. Anterior margin with a large lateral blunt tooth on each side; surface with setiferous tubercles densely distributed. Ocular area yellowish; stemmata clustered. Coronal suture short, frontal sutures long, curved, extending to base of antennae; frontoclypeal suture absent. Gula well developed subquadrangular. Antennae (Fig. 36) short, three-segmented; basal segment elongate, distal area with two setae; second segment longest, bearing an elongated sensorium and a short seta; third segment as long as sensorium, with short distal seta. Mandibles (Fig. 37) symmetrical, apex tridentate; ventral surface with comb of long setae extending from near base to near apex; inner margin with long prostheca projecting mediad. Labrum (Fig. 35) subrectangular, transverse, anterior angles rounded; basal third smoother, distal two thirds with numerous short ramose setae; anterolateral margins with long ramose setae. Maxillae (Fig. 33): cardo short, subtriangular, transverse, bearing a short fringed seta; stipes long, subrectangular, distal third with two long setae on outer margin; disc with several short fringed setae; lacinia and galea well developed, lacinia with 6-7 long setae on mesal margin, galea, elongated, with 5-6 apical setae; palp 4-segmented, first segment the shortest, with one ventral seta, remaining segments subequal in length, third segment with one lateral seta, last segment with one basal seta and apex with several short sensilla. Labium (Fig. 34) large, formed by prementum and postmentum; postmentum large, undivided, subrectangular, longer than wide, ventral surface with rugose area at base, distal third with ramose setae on lateral margin, apical corners with stout palp-like projection on each side; prementum membranous, short, transverse, forming setose lobe between palpi; palpi two-segmented, basal segment subrectangular, with long setae on outer margin; second segment shorter, bearing several setae and sensoria.

Thorax (Fig. 31 - 32, 38): strongly sclerotized, tergal plates with sagittal line. All tergal, pleural and ventral 


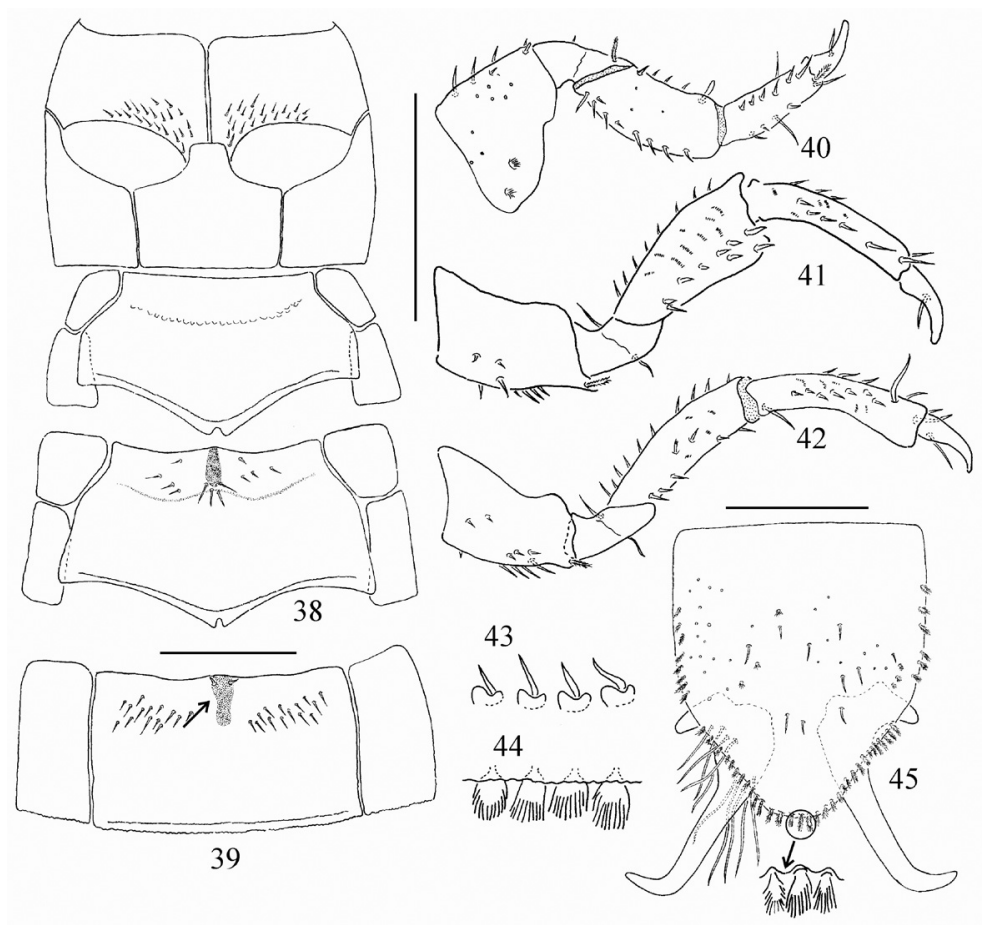

Figs. 38 - 45. Macrelmis saltensis Manzo, larva. 38 thoracic segments, ventral view; 39 first abdominal segment, ventral view; 40 prothoracic leg; 41 mesothoracic leg; 42 metathoracic leg; 43 - 44 different setae: 43 setae from head, thorax and abdomen; 44 setae posterior margin of all segments; 45 operculum, ventral view. Scale bars: figs $38,39,40,41$ and $42=0.40 \mathrm{~mm}$; fig $45=0.20 \mathrm{~mm}$.

sclerites with setiferous tubercles densely distributed like those on head (Fig. 43); tergal sclerites with small basal and lateral areas lacking tubercles (dotted lines in Fig. 30). Pronotum largest, convex, broader than long, with rounded angles. Venter of prothorax (Fig. 38) with five sclerites: episternum and epimeron on each side, and one large posteromedial sclerite (sternellum); procoxal cavity closed; setiferous tubercles more sparsely distributed than terga. Meso- and metanota shorter than prothorax (Figs 31,38). Venter of meso- and metathorax each with large subpentagonal basisternum anteriorly; episternum and epimeron on each side; coxal cavities open; setiferous tubercles sparse. Posterior margin of basisterna of meso- and metasterna with a concavity that fits into short carina of the metabasisternum and first abdominal sternite, respectively. Legs (Figs. 40 - 42) five segmented, similar in shape, those of prothorax the shortest. Coxa large, subtriangular; trochanter smaller, subtriangular; femur long, tibia long, narrower than femur, bearing hooked tarsungulus. Chaetotaxy of legs as in Figures 40, 41 and 42.

Abdomen: nine-segmented (Figs 30 - 31); terga I-VI with sagittal line; segments I-VII similar in shape, subrectangular, remaining segments tapering in width.
Terga of all segments with setiferous tubercles similar to those of thorax. Terga of segments I-VII with small suboval areas lacking tubercles. Pleural sclerites on segments I-VII; sternal sclerites of segments I-VII subrectangular; sternal plate of segment I (Fig. 39) with a longitudinal carina on middle of the anterior third. Segment VIII entire, ring-like. Segment IX elongate, conical, apex feebly emarginated; sternal area bearing gill chamber, operculum and a pair of hooks; operculum subpentagonal (Fig. 45).

Material Examined: BOLIVIA: Departamento Tarija, Itaú River, (debajo del pueblo de Itaú), 2141'57.4” S 6353'02.1' 'W, 993, m 8/iii/2006, E. Domínguez and C. Nieto colls, $1 \mathrm{O}^{\prime}$ and 5 larvae. All material deposited in collection of Instituto - Fundación Miguel Lillo, Tucumán, Argentina. ARGENTINA: Salta province:

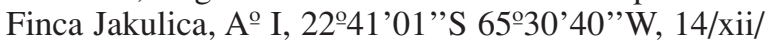
1999, E. Domínguez, F. Romero and V. Manzo colls., $1 \mathrm{O}^{\prime}$ (holotype), 2o̊ (paratype) and 1 larva (IFML).

\section{Comparative Notes}

When Macrelmis saltensis was described one larva was collected along with adults. However this larva was 
an early instar. Formal description was postponed until new material became available (Manzo 2003). Now, adults and mature larvae of $M$. saltensis were collected in Bolivia for first time.

Macrelmis was established by Motschulsky in 1859 and includes 39 species (Manzo, 2006a). The known distribution of Macrelmis includes southern United States, Central America, French Guiana, Trinidad and Tobago, Colombia, Venezuela, Ecuador, Peru, Bolivia, Brazil, Paraguay, Chile and Argentina. Hinton (1940), working with adults, separated two species-groups: granigera and striata. More recently Spangler (1997) designated the species-group: milleri. The preimaginal stages of this genus are poorly known. Bertrand $(1956,1972)$ distinguished two groups, or types, of larvae within Macrelmis: striata-type and granigera-type, based mostly on Hinton's work. So far only the larvae of three species have been described for the Neotropical region. Two species of the striata-type: $M$. striata from Mexico (Hinton 1940) and M. isis from Brazil and Argentina (Manzo \& Archangelsky 2001); and one species of the granigeratype: M. granigera from Mexico (Hinton, 1940). Larvae of three other species have also been described, but they were not assigned to any known species: two from Mexico (Hinton, 1940) and one from Peru (Spangler 1966).

The larvae of $M$. saltensis have all the characters of the granigera species-group: anterior corner of pronotum blunt, emargination of segment IX shallow and first ventrite with short longitudinal carina (character not mentioned by Bertrand). Therefore the larva of $M$. saltensis becomes the second known species of the granigera-species group.

Based on the original description of $M$. granigera (Hinton 1940), this species can be distinguished from larvae of $M$. saltensis by: (1) outer margin of mandibles with long seta; (2) labium with subrectangular prementum, notforming a lobe between palpi; (3) maxillae with cardo lacking seta, and galea with 4 long setae $(M$. saltensis has 5-6 setae); (4) larger size ( $8.00 \mathrm{~mm}$ M. granigera -5.7 $\mathrm{mm}$ M. saltensis).

\section{Distributional notes}

Macrelmis saltensis was described by Manzo (2003) based on adults from northwestern Argentina. New material of this species has been recently collected in the southern Bolivia, this becoming the first record of this species for Bolivia. Associated to M. saltensis were also collected adults and larvae of $M$. isis (Hinton 1946), a species previously only known from Brazil and Argentina (Manzo \& Archangelsky 2001). The new records for M. isis from Bolivia are:
BOLIVIA: Departamento Tarija, Bermejo River, 221'29.1”S 6936'12.6”W, 1035 m, 1/iii/2006, E. Dominguez and C. Nieto coll, $1 \mathrm{O}^{\prime}$; Salinas River (dejado del pueblo Entre Ríos), 2132'15”S 64066'55'W, 1216 m, 6/iii/2006, E. Domínguez and C. Nieto coll. 2 \&o and 1 larva; Itaú River, 2159'52.1'S 635'59.5”'W, 9/iii/ 2006, E. Domínguez and C. Nieto coll. 1 o", 1 \% and 2 larvae; Sidras, Itaú River, 2205'37.1'S 6359'12.7”W, 593 m, 8/iii/2006, E. Domínguez and C. Nieto coll. 2ơ and 2 larvae.

\section{Acknowledgments}

V. Manzo thanks the National Council of Scientific Research (CONICET, Argentina) for an internal fellowship, and William D. Shepard and an anonymous reviewer for discussion, suggestions and criticism on the manuscript. Financial support for this study was provided by the "Agencia Nacional de Promoción Científica y Tecnológica Ref. PICT 01-12529"

\section{References}

Archangelsky M. \& Manzo V. 2006. The larva of Hydora annectens Spangler \& Brown (Coleoptera: Elmidae, Larainae) and a key to New World Larainae larvae. Zootaxa, 1204, 41 - 52.

Archangelsky M. \& Manzo V. 2007. - Descripción de las larvas maduras de los géneros Stethelmis Hinton y Luchoelmis Spangler \& Staines (Insecta: Coleoptera, Elmidae). Rev. Mus. Argentino Cienc. Nat., n.s., $79-87$.

Bertrand H.P.I. 1956. Notes sur les premiers états des dryopides d'Amérique. Ann. Soc. Ent. France, 124, 97 - 139.

Bertrand H.P.I. 1965. Notes sur les premiers états des dryopides d'Amérique (Col.) (Addendum). Bull. Soc. Ent. France, 70,163166.

Bertrand H.P.I. 1972. Larves et nymphes des Coléoptères aquatiques du globe. Abbeville, France: F. Paillart. 804 pages. Brown H.P. 1970. Neocylloepus, a new genus from Texas and Central America (Coleoptera: Dryopoidea: Elmidae). Coleop. Bull., 24, 1 - 29.

Brown H.P. 1971. Neotropical Dryopoids. III. New records of Xenelmis, with description of the larva (Coleoptera: Elmidae). Coleop. Bull., 27, 95 - 101.

Brown H.P. 1981. Huleechius, a new genus of riffle beetles from Mexico and Arizona (Coleoptera, Dryopoidea, Elmidae). Pan Pac. Entomol., 57, 228 - 244.

Čiampor F. \& Ribera I. 2006. Hedyselmis opis: Description of the larva and its phylogenetic relation to Graphelmis (Coleoptera: Elmidae: Elminae). Eur. J. Entomol., 103, 627 - 636.

Hinton H.E. 1939. - An inquiry into the natural classification of the Dryopoidea based partly on a study of their internal anatomy (Coleoptera). Trans. R. Ent. Soc. London, 89, 133 - 184.

Hinton H.E. 1940. A monographic revision of the Mexican water beetles of the family Elmidae. Novit. Zool., 42, 217 - 396.

Hinton H.E. 1946. A synopsis of the Brazilian species of Elsianus Sharp. Trans. R. Ent. Soc. London, 96, 125 - 149.

Kodada J \& Jäch M.A. 1999. Roraima carinata gen. et sp. nov. and Neblinagena doylei sp. nov., two Larainae from Mount Roraima, Venezuela (Coleoptera: Elmidae). Entomol. Problems, 30, 13 29.

Lawrence J.F. 1991. Order Coleoptera. Pages 404 - 407 in Immature Insects 2. F.W. Stehr (ed.). Kendall/Hunt Publishing Co., USA. 
Manzo V. 2003. A new species of Macrelmis Motschulsky from Argentina (Coleoptera: Elmidae). Aquat. Insects, 25, 169-175.

Manzo V. 2005. Key to the South America genera of Elmidae (Insecta: Coleoptera) with distributional data. Stud. Neotr. Fauna Environ., 40, 201 - 208.

Manzo V. 2006a. Sistemática y Biología de la Familia Elmidae (Insecta: Coleoptera) en Argentina. Universidad Nacional de Tucumán, 203 pp + anexo.

Manzo V. 2006b. A review of the American species of Xenelmis Hinton (Coleoptera: Elmidae), with a new species from Argentina. Zootaxa, 1242, $53-68$.

Manzo V. \& Archangelsky M. 2001. Description of the larva of Macrelmis isis (Hinton, 1946), whit distributional notes of the species (Coleoptera: Elmidae). Tijdschr. Entomol., 144, 45-54.

Motschulsky V. 1859. Insectes des Indes orientales, et de contreés anlogues. Etudes Entomologiques, 8, 25 - 118.

Spangler P.J. 1966. - The Catherwood Foundation Peruvian Amazon Expedition XIII. Aquatic Coleoptera (Dytiscidae, Noteridae, Gyrinidae, Hydrophilidae, Dascillidae, Helodidae,
Psephenidae, Elmidae). Monographs of the Academy of Natural Sciences of Philadelphia, 14, 377 - 443.

Spangler P.J. 1990. A revision of the Neotropical aquatic beetle genus Stegoelmis (Coleoptera: Elmidae). Smithsonian Contributions to Zoology, 502, $52 \mathrm{pp}$.

Spangler P.J. 1997. - Two new species of the aquatic beetles genus Macrelmis Motschulsky from Venezuela (Coleoptera: Elmidae: Elminae). Insecta Mundi, 11, 1 - 8.

Spangler P.J. \& Santiago S. 1987. a revision of the Neotropical aquatic beetle genera Disersus, Pseudodisersus and Potamophilops (Coleoptera: Elmidae). Smithsonian Contributions to Zoology, 446, $40 \mathrm{pp}$.

Spangler P.J. \& Santiago - Fragoso S. 1992. The aquatic beetle Subfamily Larainae (Coleoptera: Elmidae) in Mexico, Central America and the West Indies. Smithsonian Contributions to Zoology, 528, 74 pp.

Springer M \& Rivas R.A. 2003. First description of the larva of Pharceonus Spangler et Santiago - Fragoso 1992 and new records for the genus (Coleoptera: Elmidae: Larainae) Aquat. Insects, 25, 219-223. 